\author{
Monika PEPLOWSKA ${ }^{1}$ \\ Dominik KRYZIA ${ }^{2}$
}

\title{
THE ASSESSMENT MODEL OF ENERGY SECURITY IN THE ROAD TRANSPORT SECTOR IN POLAND
}

\begin{abstract}
The current economic situation and adopted by the member states ofEuropean Union (including Poland) energy policy makes it increasingly looking for alternative sources of supply. This theme refers not only to the energy sector but also to the others, including the road transport sector. The future of the automotive industry is not only striving for the lowest $\mathrm{CO} 2$ emissions, but also to rationalize fuel consumption and to reduced a noise levels. Therefore, the interest of an alternative fuels such as LPG, CNG, LNG is still growing. In the current situation we should take appropriate steps to create an optimal scheme showing how changes in the structure of fuel consumption in road transport affect the level of safety in this sector. The aim of this article is to attempt at creating model for the assessment of energy security in the road transport sector in the national realities. The model based on the authors experience and pursuant of multivariate data analysis inter alia, in research and analysis of literature sources. In the first part of the article the authors define the concept ofenergy security in the sector, and then presented a four-dimensional manner of its examination - physical, economic, environmental and social - and having these criteria, bearing in mind the fact that it is impossible to measure all the elements shaping the broad energetic safety. At the end of the article, the authors attempted to design evaluation index of energy security in the Polish road transport by adopting an additive aggregation formula. Keywords: energy security, alternative fuels model, road transport.
\end{abstract}

\section{INTRODUCTION}

The main energy sources used to power vehicles are fuels resulting from the processing of crude oil, that is petrol and diesel fuel. The continuous increase in oil prices and depletion of oil fields, associated with -among others - armed conflicts in countries that are major producers of crude oil and the negative impact ofpetroleum fuels on the natural environment forces us to search for alternative fuels. The green policy of the European Union imposing standards and emission limits, especially when it comes to greenhouse gases and the development of biofuels, as exemplified by climate and energy package, is also worth noting.

In recent years, due to, inter alia, environmental and economic advantages, alternative fuels such as propane-butane, $\mathrm{CNG}$ (Compressed Natural Gas), and the condensed form of natural gas LNG (Liquefied Natural Gas) are increasingly used in combustion engines

\footnotetext{
${ }^{1}$ Monika Pepłowska, MSc, Eng., The Mineral and Energy Economy Research Institute of the Polish Academy of Sciences, Division of Minerals and Energy Sustainable Development, e-mail: monika@min-pan.krakow.pl

${ }^{2}$ D. Sc., Eng. Dominik Kryzia, The Mineral and Energy Economy Research Institute of the Polish Academy of Sciences, Division of Minerals and Energy Sustainable Development, e-mail: kryzia@min-pan.krakow.pl
} 
used in the transportation. The importance of electric or hydrogen powered vehicles is also increasing.

In Poland, currently the most popular alternative fuel used in transport is LPG. The use of this fuel ranks Poland among the global leaders (with 2.6 million vehicles powered by LPG Poland has a leading position in the world; second only to Turkey).However, some public transport companies have used LNG for more than ten years as well as CNG in recent years ${ }^{34}$.

The development of alternative fuels market will be supported by The Directive 2014/94/EU of the European Parliament and of the Council of 22 October 2014 on the deployment of alternative fuels infrastructure (assumptions until 2020 ), part of the „Clean Energy for Transport” package, which obliges Member States to develop infrastructure for alternative fuels. This package indicates the maximum distance between refueling stations, which cannot exceed $150 \mathrm{~km}$ for CNG, $400 \mathrm{~km}$ for LNG and $300 \mathrm{~km}$ for hydrogen ${ }^{5}$.

The increasing requirements of environmental protection resulting from the EU policy and the potential economic benefits are responsible for the increased use of alternative fuels and their increased share in fuel consumption in transport. This in turn has an impact on the energy security in the sector. This is due to the diversification effect given thedifferences between individual fuels. At the same time monitoring of energy security in the transport sector is of vital importance due to its growing share in the market. Thus, the aim of this study was to create a model capable to determine how a change in the structure of fuel consumption in the road transport sector will affect the level of energy security in the sector.

\section{ENERGY SAFETY}

The issue of energy security is discussed in many publications by specialists in various fields. However, identification of the factors affecting the energy security is essential for any scientist. What is more, this issue is covered by some of the most important national legal acts and a program documents, such as The Doctrine of energy safety management ${ }^{6}$, The Energy Law Act ${ }^{7}$, The Energy Policy of Poland until $2030^{8}$.

Given all the definitions contained in the above-mentioned documents, it can be said that energy security is a condition of the economy that allows to cover the current and prospective demand for fuel and energy in a technically and economically viable manner while minimizing the negative impact of the energy sector on the environment and the

\footnotetext{
${ }^{3}$ M. Orzechowska, M. Filip, A. Szurlej, Economic and environmental aspects of using CNG in urban public transport - based on the experience of MPK Rzeszów, Logistyka, nr 4/2014, p. 47564763.

${ }^{4}$ M. Orzechowska, D. Kryzia, Analiza SWOT wykorzystania gazu ziemnego w transporcie drogowym w Polsce, Polityka Energetyczna - Energy Policy Journal, 2014, nr 17, vol.3, p.321-332.

${ }^{5}$ The Directive of the European Parliament and the Council on the deployment of infrastructure for alternative fuels, Dz. Urz. UE L 307 z 28.12.2014, s.1.

${ }^{6}$ The doctrine of energy safety management. Ministry of Economy and Labour. Warszawa, May 2004

${ }^{7}$ The Energy Law Act of April 10th 1997 (Journal of Laws of 2012, No. 1059, with subsequent amendments)

${ }^{8}$ The Energy Policy of Poland until 2030. Ministry of Economy, December 2009
} 
living conditions of the population ${ }^{9}$.Actually, there are four dimensions of energy security, i.e. physical, economic, ecological and social development aspect, which can be distinguished.

The main objective of creating energy securityis ${ }^{10}$ :

- in physical dimension: ensuring the continuity of supplies of a certain quality to end users of energy enough to cover the energy demand;

- in economic dimension: ensuring competitive and stable prices for the end users;

- in ecological dimension: ensuring a certain level of impact of the energy sector on the natural environment;

- in social dimension: ensuring a certain level of impact of the energy sector on social life.

In order to develop the assessment model of energy security in the road transport sector, it is necessary to define the concept of energy security in the transport sector, which ought to be analyzed.This can be understood as ensuring reliable uninterrupted supply of fuel in an amount sufficient to meet current and prospective needs of the transport sector, at a reasonable price, with minimal impact on the environment and social life. The above definition is the starting point for attempts to create a model for the assessment of energy security in the road transport sector.

\section{THE ASSESSMENT MODEL OF ENERGY SECURITY IN THE ROAD TRANSPORT SECTOR - THE MODEL'S CHARACTERISTICS}

The model is based on a multidimensional data analysis that allows to determine the aggregate value of energy security indicator.

Imprecise and multidimensional concept of energy security can be evaluated on the basis of many criteria (features). As a result, there is a whole set of features, each relating to another dimension of energy security. Taken alone, none of them allows to fully determine the status of energy security. As a result, it is difficult to find the appropriate set of attributes describing the state of energy security. A different set of features applies for short term and long term energy security, its external and internal dimension ${ }^{11}$.

Usually, the selection of energy security criteria and determination of their significance is carried out in an authoritative manner on the basis of the evidence available. This typically comes down to determining the selected features of partial evaluation on the basis of which an overall assessment of energy security is formulated in an intuitive way. As a result, the analysis of energy security is vitiated by an element of subjectivity ${ }^{12}$.

This paper, due to the inability to measure all the elements characterizing the widely understood energy security, adopted a list of partial evaluation criteria, including the indicators of a quantitative and qualitative nature. The selected properties are aimed at

\footnotetext{
${ }^{9}$ J. Paska, Economic dimension of power supply safety and reliability, „,Rynek Energii” no 2, 2013

${ }^{10}$ D. Kryzia, K. Kryzia, Gaz ziemny a bezpieczeństwo energetyczne, „Wiertnictwo Nafta Gaz”, v. 28, no. 1-2, 2011, p. 217-225

${ }^{11}$ R. Riedel, Supranationalisation of energy security of Europe : theoretical approaches. Centrum Europejskie Natolin, Warszawa, 2010

${ }^{12}$ D. Staśko, M. Kaliski, An evaluation model of energy safety in Poland in view of energy forecasts for 2005-2020. Archives of Mining Sciences, no. 51/3, 2006, p. 311-346
} 
illustrating the degree of implementation of the objectives, set out in the definitions of energy security.

The authors suggest the following sets criteria characterizing the individual dimensions. For the assessment of energy security in the physical dimension, the following criteria were assumed:

- Number of gas stations- the more gas stations located in an area the greater availability of fuel, which effects the higher value energy security;

- Technical ability to transport and storage- seen in terms of the availability of transport infrastructure and the storage as well as facility of handling work carried out in various logistics processes. The easier they are to carry out the higher level of energy security, provides the basic fuel;

- Possibility of fuel substitution- possibility to replace the fuel the other kind of fuel depends on the number of fuels which may be used interchangeably, and the rate at which this fuel may be implemented A large number of fuels that substitutes for kind of fuel and the high degree to which fuel can be realized a positive effect on energy security;

- Amount of imported fuel in the fuel sector- fuel from domestic production seen by the public as safer than imported fuel, the higher the amount of imported fuel in the fuel sector, the lower the level of energy security provides this kind of fuel;

- Amount of domestic raw material in the production of fuel- national natural resources are seen as safer than resources from other countries. The higher the amount of domestic raw material in the production of fuel destined for the domestic market, the higher the level of energy security;

- Resource sufficiency of raw material for production of fuels- The longer the sufficiency of resources of raw material to produce fuel (indicating the possibility of operating profitability while providing specific raw material extraction) the level of energy security is higher.

Taking into account the economic dimension, the following features were adopted:

- Price of fuel- the unit price of fuel is a key economic aspect. The lower it is, the higher the level of energy security provides this fuel;

- Volatility of fuel prices- fuel prices are constantly changing, they often hesitate and grow, the greater the risk of pricing the fuel. Price stability is a direct and a key determinant of energy security in economic terms;

- Efficient use of fuel- fuel supply heat machine working according to a given thermodynamic cycle is characterized by specific values of the physical and chemical parameters such as: octane/cetane number. To power diesel engines in Sabathe circulation used in diesel and for the spark ignition engines to power the working Otto cycle - petrol. Compressed natural gas (CNG) can power both types of engines and gas turbines in Brayton-Joule cycle, while fuel in the form of LPG - spark engines. Thermodynamic process by which heat engine operates determines the thermal efficiency of the unit responsible for a unit amount of fuel needed to obtain mechanical energy. The less fuel units is needed to obtain a unit of energy, the higher the energy security it provides. This fact applies to economic and physical dimensions. The price of fuel determines the value of the cost of vehicle operation;

- Level of investment needed for infrastructure development - the value of the required investment (in terms of production, transport and distribution) to the fuel is higher, the lower level is ensured energy security; 
- Relative value adjustment expenses incurred for the vehicle to power the fuel- the use of fuels such as CNG and LPG requires capital expenditure necessary to adapt the vehicle to the fueling. Another option is to purchase a vehicle with an installed system (higher purchase cost of the vehicle). The relative level of costs incurred to adapt the vehicle to power the fuel forms of energy security value. Higher cost of expenditures lowers the level of security in the economic dimension.

To determine the energy security in the ecological dimension, the following criteria were adopted:

- Value of $\mathrm{CO} 2$ emissions- carbon dioxide is a major greenhouse gas, its volume of emissions per unit of energy contained in the fuel depends on the fuel composition (especially compared with the hydrogen to the carbon). The low value of this ratio favorably affect the value of the energy security provided by this fuel;

- Value of SO2 emissions- Sulphur dioxide in the atmosphere and hydrosphere, inhibits the growth of living organisms, reduces water quality and accelerates the degradation of soils. The low value of this ratio favorably affect the value of the energy security provided by this fuel;

- Value of NOx emissions- Presence of nitrogen oxides in the atmosphere are a serious threat to living organisms and cause the formation of photochemical smog. NOx emissions per unit of fuel depends on the nitrogen content of the fuel and combustion process. The low value of this ratio favorably affect the value of the energy security provided by this fuel;

- Value of dust emissions- dust is a major pathogen (carcinogen). The level of particulate emissions per unit of fuel depends on the type and parameters, and the combustion process as well as the efficiency of the device used reductive.

- The low value of this ratio favorably affect the value of the energy security provided by this fuel;

- Level of pollution during the production of fuel-Fuel production requires a number of processes which produce various types of waste and pollution. Many of these processes require energy input, which is also a cause of the generation of waste and pollution. With the increase in the value of pollutants formed during manufacture of the units of fuel decreases the value of energy security in the ecological dimension afforded by this fuel.

From the social dimension point of view, the features characterizing energy security include:

- Social acceptance: the higher level of social acceptance in the field operated the fuel is, the higher value energy security in the social dimension provides by this fuel;

- Social costs associated with the use of fuel- all the losses suffered by third parties or society as a whole as a result of fuel use are called social costs. The costs are higher, the lower the level of energy security in the social dimension provides a fuel.

The proposed sets of criteria are preliminary and are based on analysis of the literature, previous research and authors' experience. There is a need for further studies in order to optimize the attributes necessary to carry out a proper assessment of energy security.

The input data on the individual characteristics can be qualitative or quantitative. The values for selectedfeatures of partial assessment of energy security (e.g. the price) will be determined on the basis of statistical features, available for observation or measurement. For other features of partial assessment of energy security (e.g. social acceptance), the values will be determined on the basis of surveys prepared by experts. 
Part of the statistical characteristics is expressed in different units. Therefore, it is necessary to convertthem to comparable values (dimensionless quantities). For this purpose, standardization, normalization and ratiometric conversion, so as to convert all the features into stimulants, should be done.

One of the most complicated stages of building an aggregate indicator reflecting themultidimensional state of energy security is to determine the validity of the criteria and the dimensions, i.e. the determination of weights. The weights of individual characteristics and dimensions play an important role in the overall assessment of the analyzed phenomenon, as they often significantly affect the final result of the analysis. The weights characterizing the relevance of a particular criterion or dimension in assessing the aggregate energy security are usually determined on the basis of experts' opinions ${ }^{131415}$.

The energy security evaluation index is the most commonly calculated using additive aggregation formula.The aggregate indicator should be relative, so that it could be easily compared. Therefore,partial indicators characterizing energy security in a given dimension should be standardized in order to assign themstandardized range of values, e.g. from 1 to 10.The interpretation of values for the so-created index is as follows: the higher the index value, the higher the level of energy security in the road transport sector.

Schematic model of the assessment of energy security in the road transport sector is shown in Figure 1.

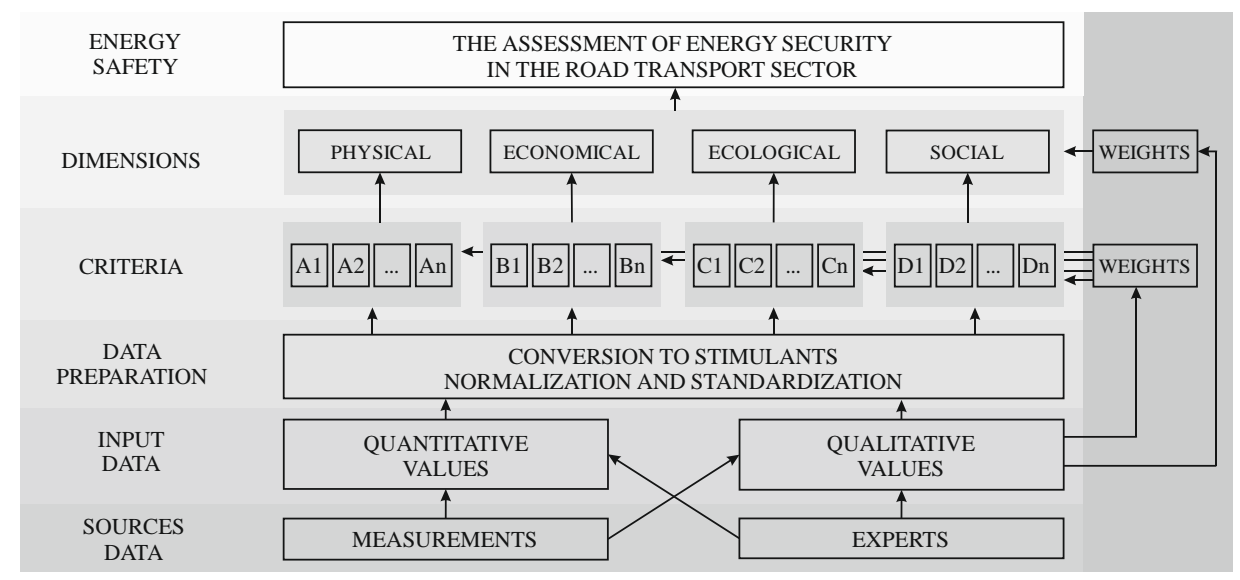

Fig.1. The assessment model of energy security in the road transport sector Source: own work

\footnotetext{
${ }^{13}$ D. Staśko, M. Kaliski, An evaluation model of energy safety in Poland in view of energy forecasts for 2005-2020. Archives of MiningSciences, no. 51/3, 2006, p. 311-346

${ }^{14}$ D. Kryzia, K. Kryzia, Gaz ziemny a bezpieczeństwo energetyczne, Wiertnictwo Nafta Gaz, t. 28, z. 1-2, 2011, s. 217-225

${ }^{15}$ D. Kryzia, K. Kryzia, Porównanie kopalnych nośników energii pod względem możliwości zapewnienia bezpieczeństwa energetycznego. [W:] Bezpieczeństwo energetyczne - rynki surowców i energii. Wydawnictwo Wyższej Szkoły Bezpieczeństwa Poznań, 2011
} 


\section{SUMMARY}

The level of energy security in the road transport sector is equal to the sum of the products of the energy security provided by individual fuels and the shares of these fuels in the domestic fuel consumption by motor vehicles. This is a consequence of an additive aggregation formula adopted to construct the evaluation index of energy security in the transport sector.

Taking into account the European Union's policy in the field of market development of alternative fuels and environmental protection, it should be noted that the current structure of automotive fuel consumption will evolve towards a greater share of alternative fuels such as biofuels, LPG, CNG, LNG and others. This will reduce the share of petroleumbased fuels such as gasoline and diesel fuels in favor of fuels produced from biomass and natural gas. These raw materials, especially biomass, provide a different level of energy security in each of the four dimensions because of their different structure. This is very distinctive for the aforementioned fuels. At the same time, low similarity between these fuels and petroleum fuels is accompanied by increasing importance of diversification effect, favorably affecting the energy security status. The proposed model allows assessing the energy security in the road transport sector.

\section{BIBLIOGRAPHY}

[1] Doktryna zarządzania bezpieczeństwem energetycznym. Ministerstwo Gospodarki i Pracy. (The doctrine of energy safety management. Ministry of Economy and Labour). Warszawa, May 2004.

[2] Kryzia D., Kryzia K., Gaz ziemny a bezpieczeństwo energetyczne (Natural gas and energy security), Wiertnictwo Nafta Gaz, v. 28, no. 1-2, 2011, p. 217-225.

[3] Kryzia D., Kryzia K., Porównanie kopalnych nośników energii pod względem możliwości zapewnienia bezpieczeństwa energetycznego (Comparison of fossil energy sources in terms of energy security). [W:] Bezpieczeństwo energetyczne - rynki surowców i energii. Wydawnictwo Wyższej Szkoły Bezpieczeństwa Poznań, 2011.

[4] Orzechowska M., Filip M., Szurlej A., Economic and environmental aspects of using CNG in urban public transport-based on the experience of MPK Rzeszów, Logistyka, no. 4/2014, p. 4756-4763.

[5] Orzechowska M., Kryzia D., Analiza SWOT wykorzystania gazu ziemnego w transporcie drogowym w Polsce, Polityka Energetyczna - Energy Policy Journal, 2014, nr 17, vol.3, p. 321-332.

[6] Paska J., Ekonomiczny wymiar bezpieczeństwa elektroenergetycznego $i$ niezawodności zasilania (Economic dimension of power supply safety and reliability), Rynek Energii, no. 2, 2013.

[7] Polityka Energetyczna Polski do roku 2030 (The Energy Policy of Poland until 2030). Ministry of Economy, December 2009.

[8] Riedel R., Supra nacjonalizacja bezpieczeństwa energetycznego w Europie: Podejścia teoretyczne.(Supranationalisation of energy security of Europe: theoretical approaches). Centrum Europejskie Natolin, Warszawa, 2010.

[9] Staśko D., Kaliski M., Model oceny bezpieczeństwa energetycznego Polski $w$ aspekcie prognoz energetycznych na lata 2005-2020 (An evaluation model 
of energy safety in Poland in view of energy forecasts for 2005-2020). Archives of Mining Sciences, no. 51/3, 2006, p. 311-346.

[10]The Directive of the European Parliament and the Council on the deployment of infrastructure for alternative fuels, Dz.Urz. UE L $307 \mathrm{z}$ 28.12.2014, s.1.

[11] Ustawa Prawo energetyczne z dnia 10 kwietnia 1997 roku. Dz. U. z $2012 \mathrm{nr}$ 1059, z późn. zm. (The Energy Law Act of April 10th 1997. Journal of Laws of 2012, No. 1059, with subsequent amendments).

\section{MODEL OCENY STANU BEZPIECZEŃSTWA ENERGETYCZNEGO W SEKTORZE TRANSPORTU DROGOWEGO W POLSCE}

Aktualna sytuacja ekonomiczna oraz przyjętą przez kraje członkowskie Unii Europejskiej (w tym również przez Polskę) polityka energetyczna sprawia, że coraz częściej poszukuje się alternatywnych źródeł zasilania. Temat ten tyczy się nie tylkosektora energetycznego, ale również innych, w tym także sektora transportu drogowego. Przyszłość motoryzacji to nie tylko dążenie do jak najniższej emisji $\mathrm{CO}_{2}$, ale również racjonalizacja zużycia paliwa i redukcja poziomu hałasu. W związku z tym obserwuje się zainteresowanie paliwami alternatywnymi takimi jak np. LPG, CNG, LNG. W obecnej sytuacji należy poczynić odpowiednie kroki, aby stworzyćoptymalnyschemat obrazujący jak zmiany struktury zużycia paliw w transporcie drogowym wpływają na poziom bezpieczeństwa tego sektora. Celem niniejszego artykułu jest próba stworzenia modelu oceny bezpieczeństwa energetycznego w sektorze transportu drogowego w realiach krajowych. Model ten powstał w oparciu o doświadczenie autorów oraz na podstawie wielowymiarowej analizy danych pochodzacych między innymi z prowadzonych badań oraz analizy źródeł literaturowych. W pierwszej części artykułu zajęto się właściwym zdefiniowaniem pojęcia bezpieczeństwa energetycznego w omawianym sektorze, a następnie zaprezentowano czterowymiarowy sposób jego rozpatrywania - fizyczny, ekonomiczny, ekologiczny ispołeczny - oraz charakteryzujące je kryteria,mając na uwadze fakt, że niemożliwe jest zmierzenie wszystkich elementów kształtujących szeroko rozumiane bezpieczeństwo energetyczne. Na koniec autorzy podjęli próbę konstrukcji wskaźnika oceny bezpieczeństwa energetycznego w sektorze polskiego transportu drogowego przyjmując addytywną formułę agregacji.

Słowa kluczowe: bezpieczeństwo energetyczne, paliwa alternatywne, model, transport drogowy.

DOI:10.7862/rz.2016.hss.28

Przesłano do redakcji: listopad 2015

Przyjęto do druku: lipiec 2016 